\title{
SYMBIOTIC EFFECTIVENESS OF BRAZILIAN RHIZOBIAL STRAINS IN IMPROVING N-FIXATION AND PRODUCTIVITY OF COWPEA IN MINNA, SOUTHERN GUINEA SAVANNA OF NIGERIA
}

\author{
Olaotan Abimbola ADEDIRAN ${ }^{1}$, Akim Osarhiemen OSUNDE ${ }^{2}$, Abdullahi BALA $^{2}$, \\ Mahamadi DIANDA $^{3}$, Haruna IBRAHIM ${ }^{1}$, Olusoji Olaolu OLUFAJO ${ }^{4}$, \\ Johnson Akinade OLADIRAN ${ }^{1}$ \\ ${ }^{1}$ Department of Crop Production, Federal University of Technology, \\ Minna, P.M.B. 65, Minna - Nigeria \\ ${ }^{2}$ Department of Soil Science and Land Management, Federal University of Technology, \\ Minna, P.M.B. 65, Minna - Nigeria \\ ${ }^{3}$ International Institute for Tropical Agriculture, Ibadan Station - Nigeria \\ ${ }^{4}$ Department of Agronomy, Ahmadu Bello University, Zaria - Nigeria \\ ${ }^{*}$ Corresponding author. E-mail: o.adediran@futminna.edu.ng
}

\begin{abstract}
In a bid to evaluate the effectiveness of two Brazilian rhizobial strains in improving nitrogen fixation and productivity of cowpea (Vigna unguiculata (L.) Walp) in the southern Guinea savanna of Nigeria, field trials were conducted in 2016 and 2017. Four rhizobial inoculation levels (control, inoculation with BR 3262, BR 3267 and application of $90 \mathrm{Kg} \mathrm{N} \mathrm{ha}^{-1}$ ) and three varieties (IT93K-452-1, IT99K573-1-1 and TVx 3236) were arranged in randomized complete block design. Inoculation with BR 3267 significantly increased nodule number by $27 \%$ over the control in 2017 and there was significant variation in the response of the varieties to inoculation in the two years in respect of nodule weight. Plants fertilized with $90 \mathrm{Kg} \mathrm{N} \mathrm{ha}{ }^{-1}$ consistently had the least number of nodules, weight and percentage of effective nodules in the two years. N-uptake and shoot biomass yield was however significantly higher in the N-fertilized and uninoculated plants than plants inoculated with the BR strains. Plants inoculated with both strains fixed significantly lower nitrogen than the uninoculated plants. However, the inoculated plants partitioned greater nitrogen to their seeds having significantly higher \% protein in their seeds than the uninoculated plants. Plants fertilized with $90 \mathrm{~kg} \mathrm{Nha}^{-1}$ had the highest grain yield $\left(1761.2 \mathrm{~kg} \mathrm{ha}^{-1}\right)$ which was at par with the value recorded in the uninoculated plants $\left(1479.60 \mathrm{Kg} \mathrm{ha}^{-1}\right)$ but significantly higher than the values recorded in the inoculated plants (1320.1-1338.0 Kg N ha-1). It could therefore be concluded that the BR strains tested in this study are not more effective than the indigenous strain in improving $\mathrm{N}$-fixation and productivity of cowpea in the study area.
\end{abstract}

Keywords: BR strains, nodulation, n-fixation, biomass yield, grain yield.

\section{Introduction}

Over the years, food requirements have increased while land availability has become less due to increase in population and urban development. Thus, the only way to increase agricultural production is to increase the yield of individual crop per unit area of land. Low crop productivity is a general problem facing most farming systems in sub-Saharan Africa. These low yields are pronounced in grain legumes and are often associated with declining soil fertility and reduced $\mathrm{N}_{2}$-fixation [MFILINGE \& al. 2014]. Cowpea which is the most important legume in Nigeria is the most affected with an average yield of $450 \mathrm{~kg} \mathrm{ha}{ }^{-1}$ [OMOTOSO, 2014]. 
Rhizobial inoculation has been reported by a number of workers to improve the yield of legumes and enhance soil fertility [SINGH \& al. 1997; KENNEDY \& al. 2004; MATIRU \& DAKORA, 2004; HAN \& LEE, 2005; ZHOU \& al. 2006; ELKOCA \& al. 2007; HUANG \& ERICKSON, 2007; BEJANDI \& al. 2011; SCHWEIGER \& al. 2012]. Effective symbiotic relationship depends on the cultivar and the rhizobium strain [FALL \& al. 2003]. Rhizobia strains differ in their ability to fix atmospheric nitrogen [FALL \& al. 2003]. A rhizobium strain can only be considered effective if it can fix nitrogen in the nodules of the host plant. The symbiotic effectiveness of a rhizobium strain is an estimation of host growth promotion and is usually based on the enhancement of plant shoot dry weight upon inoculation [LARANJO \& al. 2014]. Many soils are heavily infested with ineffective rhizobia capable of inducing nodulation without host benefit [FENING \& DANSO, 2002]. Under such condition, inoculation with highly competitive and effective strain of rhizobia is needed to replace the ineffective native rhizobia. Inoculation is usually done to ensure the availability of the correct bacteria species and an effective strain of that species [BASHAN \& al. 2014]. This study therefore aimed to evaluate the effectiveness of two Brazilian rhizobial strains in improving the nitrogen fixation and productivity of cowpea in Minna, southern Guinea savanna of Nigeria.

\section{Material and methods}

The study was conducted on three farmers' fields $\left(09^{\circ} 27.832^{\prime} \mathrm{N} 006^{\circ} 25.375^{\prime} \mathrm{E}, 09^{\circ}\right.$ $31.203^{\prime} \mathrm{N} 006^{\circ} 27.678^{\prime} \mathrm{E}$ and $09^{\circ} 28.026^{\prime} \mathrm{N} 006^{\circ} 25.325^{\prime} \mathrm{E}$ ) (but researcher managed) in Minna southern Guinea savanna of Nigeria. The climate of Minna is sub humid with mean annual rainfall of about $1284 \mathrm{~mm}$ and a dry season of about 5 months duration occurring from November to March. The mean maximum temperature (about $33.5{ }^{\circ} \mathrm{C}$ ) remains high throughout the year [OJANUGA, 2006]. The physiographic characteristics of Minna area consist of gently undulating high plains developed on basement complex rocks made up of granites, migmatites, gneisses and schists. Inselbergs of "older granites" and low hills of schists rise conspicuously above the plains. Beneath the plains, bedrock is deeply weathered and constitutes the major parent material (saprolites) [OJANUGA, 2006].

The treatments consisted of four levels of rhizobial inoculation (control, inoculation with BR 3262, BR 3267 and application of $90 \mathrm{~kg} \mathrm{~N} \mathrm{ha}^{-1}$ ) and three cowpea varieties (IT93K452-1, IT99K-573-1-1 and TVx 3236). These were factorial combined to give twelve treatments combinations which were arranged in randomized complete block design. There were three replicates and each farmer's field served as a replicate. Gross plot size was 3.75 $\mathrm{m} \times 4 \mathrm{~m}\left(15 \mathrm{~m}^{2}\right)$ consisting of five rows, and net plot size was $2.25 \mathrm{~m} \times 4 \mathrm{~m}\left(9 \mathrm{~m}^{2}\right)$ consisting of three rows, with $75 \mathrm{~cm}$ spacing between rows. Intra and inter row spacing of $20 \times 75 \mathrm{~cm}$ were maintained. Three seeds per hole were planted and the resultant seedlings were later thinned to two per stand at seven days after planting. Simultaneously, maize (the reference crop) was planted in between the cowpea plots and intra and inter row spacing of $75 \mathrm{~cm} \times 75$ $\mathrm{cm}$ was maintained.

All the plots received basal application of $45.8 \mathrm{~kg} \mathrm{P}_{2} \mathrm{O}_{5}$ and $40 \mathrm{~kg} \mathrm{~K}_{2} \mathrm{O}$ ha ${ }^{-1}$ at planting. Nitrogen was applied to the plots that received $90 \mathrm{~kg} \mathrm{~N} \mathrm{ha}^{-1}$ in two split. Twenty five percent was applied at 3 weeks after planting and the remaining $75 \%$ was applied at flowering. The inoculants were applied at the rate of $5 \mathrm{~g}$ per $\mathrm{kg}$ seed using the slurry method which was done by first coating the seeds with a sticker (solution of $85 \mathrm{ml}$ water and $15 \mathrm{~g}$ sugar) before applying the inoculant to the coated seeds [IITA and $\mathrm{N}_{2}$ Africa, 2014]. 
At 50\% flowering, the shoot of cowpea plants within $1 \mathrm{~m}$ along the ridge were cut at the soil surface, put inside a paper envelope. The roots were carefully dug out with a spade and the soil mass around the roots were carefully washed off to recover the nodules. The nodules were counted and packed inside a paper envelope. Ten nodules were selected at random from each treatment and were dissected into halves. Nodules that appear pinkish, reddish or wine in colour are considered effective as they contain leghemoglobin which is an important enzyme for nitrogen fixation in rhizobia [TAJIMA \& al. 2007]. At 50\% tasseling, the shoot of the maize plants were also cut at soil surface and put inside a paper envelope. All the enveloped plant materials were then oven dried at $70{ }^{\circ} \mathrm{C}$ for 48 hours to obtain their dry weight and weighed on a Mettler balance.

The dried shoots (cowpea and maize) were then used for the determination of total $\mathrm{N}$ in shoot for $\mathrm{N}$-uptake and $\mathrm{N}$ fixation estimation using the $\mathrm{N}$-difference method. Micro Kjeldahl's oxidation method involving digestion and distillation was used for the determination of the $\mathrm{N}$ in the shoot of the cowpea plant and the reference crop. $\mathrm{N}$ fixed was calculated using the formula:

$$
\text { Total } \mathrm{N} \text { in plants }=\frac{\text { Dry weight } \times \% \mathrm{~N} \text { in plants }}{100}
$$

$\mathrm{N}$ fixed $(\mathrm{NDFA})=$ Total $\mathrm{N}$ in legume - Total $\mathrm{N}$ in reference crop [YAKUBU \& al. 2010]. The total $\mathrm{N}$ in seeds were also determined using the Micro Kjeldahl's oxidation method and the $\% \mathrm{~N}$ was multiplied by a factor of 6.25 to obtain the protein content.

Data collected were subjected to analysis of variance using the General Linear Model procedure of Minitab software. Differences between the means were separated using Least Significant Difference (LSD) at 5\% level of probability.

\section{Results}

\section{Nodule number}

The nodule number was significantly affected by rhizobial inoculation and year but the varieties were similar in response in respect of nodule number (Table 1). Figure 1 shows the interaction between year and inoculation on nodule number. In 2016, there was no significant difference between the number of nodules recorded in the inoculated and uninoculated plants. However, plants inoculated with BR 3262 produced significantly higher number of nodules than plants fertilized with $90 \mathrm{~kg} \mathrm{~N} \mathrm{ha}^{-1}$. In 2017 however, inoculation with BR 3267 significantly increased nodule number by $27 \%$ over the control. Plants fertilized with $90 \mathrm{~kg} \mathrm{~N} \mathrm{ha}^{-1}$ had the least number of nodules in the two years.

\section{Nodule dry weight}

The nodule dry weight was significantly influenced by rhizobial inoculation $(\mathrm{P}<$ $0.01)$ and interaction between year, inoculation and variety $(\mathrm{P}<0.05)$ (Table 1). Table 2 shows the interaction between year, inoculation and variety in respect of nodule dry weight. Inoculated and uninoculated IT93K-452-1 plants had similar nodule dry weight in both years. However, the uninoculated plants and plants inoculated with BR 3267 had the highest nodule dry weight which were significantly higher than the values recorded in plants fertilized with $90 \mathrm{~kg} \mathrm{~N} \mathrm{ha}^{-1}$ in 2016 and 2017 respectively. Similarly, in IT99K-573-1-1 variety, there was no significant difference between the nodule dry weight of the inoculated and uninoculated plants in 2016 but in 2017, the uninoculated plants and plants inoculated with BR 3267 had significantly heavier nodules than the same variety inoculated with BR 3262 . There was no 
significant difference between nodule weight of the inoculated and uninoculated TVx 3236 plants in both years. Plants fertilized with $90 \mathrm{~kg} \mathrm{~N}^{-1}$ had the lightest nodules across the three varieties in the two years.

\section{Nodule effectiveness}

Highly significant difference $(\mathrm{P}<0.001)$ exists between the inoculation treatments in respect of percentage of effective nodules and the interaction between year, inoculation and variety was equally significant (Table 1). The interaction between year, inoculation and variety in respect of nodule effectiveness is presented in Table 3. There was no significant difference between the percentage of effective nodules of inoculated, uninoculated and $90 \mathrm{~kg}$ $\mathrm{N} \mathrm{ha}^{-1}$ fertilized IT93K-452-1 plants in 2016. Similarly in 2017, there was no significant difference between the \% of effective nodules recorded in inoculated and uninoculated IT93K-452-1 plants but nodules obtained from plants fertilized with $90 \mathrm{~kg} \mathrm{~N} \mathrm{ha}^{-1}$ had significantly lower \% of effective nodules than the uninoculated plants and those inoculated with BR 3262.

IT99K-573-1-1 plants inoculated with BR 3262 had significantly higher percentage of effective nodules $(90 \%)$ than plants inoculated with BR $3267(40 \%)$ and plants fertilized with $90 \mathrm{~kg} \mathrm{~N} \mathrm{ha}^{-1}$ (46.67\%) in 2016. In 2017, the uninoculated plants produced significantly higher number of effective nodules than plants fertilized with $90 \mathrm{~kg} \mathrm{~N} \mathrm{ha}^{-1}$. Inoculated and uninoculated TVx 3236 plants had similar number of effective nodules which were significantly higher than the values recorded in plants fertilized with $90 \mathrm{~kg} \mathrm{~N} \mathrm{ha}^{-1}$ in 2016 . In 2017 , the percentage of effective nodules recorded in the inoculated, uninoculated and $90 \mathrm{~kg}$ $\mathrm{N} \mathrm{ha}^{-1}$ fertilized TVx 3236 plants were similar (Table 3).

\section{Nitrogen fixation}

Nitrogen fixation was significantly affected by rhizobial inoculation and the varieties also differ significantly in their ability to fix nitrogen $(\mathrm{P}<0.01)$. Similar trend were observed in respect of $\mathrm{N}$-fixation in the two years (Table 1). The uninoculated plants fixed significantly higher nitrogen than plants inoculated with BR 3262 and BR 3267 which fixed similar amount of N. (Figure 2a). IT93K-452-1 and IT99K-573-1-1 plants fixed similar amount of $\mathrm{N}$ which were significantly higher than the amount fixed by TVx 3236 plants (Figure 2b).

\section{Nitrogen uptake}

Highly significant difference exists $(\mathrm{P}<0.01)$ between the inoculation treatments and varieties in respect of $\mathrm{N}$-uptake but the trend observed in the two years were similar (Table 1). N-uptake was significantly higher in the uninoculated plants and plants fertilized with $90 \mathrm{~kg} \mathrm{~N} \mathrm{ha}^{-1}$ than the inoculated plants (Table 4). IT93K-452-1 and IT99K-573-1-1 plants had similar $\mathrm{N}$-uptake values which were significantly higher than the values recorded in TVx 3236 plants (Table 5).

\section{Shoot biomass yield}

The shoot biomass yield was significantly affected $(\mathrm{P}<0.01)$ by rhizobial inoculation and variety and similar trends were observed in the two years (Table 1). The control plants and plants fertilized with $90 \mathrm{~kg} \mathrm{~N} \mathrm{ha}^{-1}$ had similar shoot biomass yield which were significantly higher than the value recorded in plants inoculated with BR 3267 but at par with the biomass of plants inoculated with BR 3262 (Table 4). IT93K-452-1 and IT99K- 
Olaotan Abimbola ADEDIRAN \& al.

573-1-1 plants had similar shoot biomass yield values which were significantly higher than the values recorded in TVx 3236 plants (Table 5).

\section{Seed protein}

The seed protein content was significantly influenced $(\mathrm{P}<0.01)$ by rhizobial inoculation and variety. The trend observed in the two years were similar (Table 1). The control plants partitioned significantly lesser quantity of $\mathrm{N}$ to the seeds as the percentage protein recorded in seeds of the control plants were significantly lesser than the value recorded in the inoculated plants and plants fertilized with $90 \mathrm{~kg} \mathrm{~N}^{-1}$. IT93K-452-1 variety had the highest seed protein content and the values recorded in IT99K-573-1-1 and TVx 3236 were at par (Table 5).

\section{Grain Yield}

The grain yield was significantly influenced $(\mathrm{P}<0.05)$ by rhizobial inoculation but the varieties were not significantly different in their grain yield (Table 1). Plants fertilized with $90 \mathrm{~kg} \mathrm{~N} \mathrm{ha}^{-1}$ had the highest grain yield $\left(1761.2 \mathrm{~kg} \mathrm{ha}^{-1}\right)$ which was at par with the value recorded in the uninoculated plants $\left(1479.60 \mathrm{~kg} \mathrm{ha}^{-1}\right)$ but significantly higher than the values recorded in the inoculated plants (1320.1-1338.0 $\mathrm{kg} \mathrm{N} \mathrm{ha}^{-1}$ ) (Figure 3).

\section{Discussion}

The significantly higher biomass and grain yield obtained in plants fertilized with $90 \mathrm{~kg} \mathrm{~N} \mathrm{ha}{ }^{-1}$ than the inoculated plants could be an indication that the symbiosis of the inoculant strains with the varieties were not fixing enough nitrogen that the plant need for optimum productivity. In the experiment carried out by FENING \& al. (2001) to assess the potential of improving $\mathrm{N}$ fixation in cowpea in Ghananian soils, it was reported that all the 45 cowpea cultivars used showed significant response to increasing $\mathrm{N}$ fertilizer application to a particular level, indicating that $\mathrm{N}$ fixation was not providing the plants with sufficient $\mathrm{N}$ for maximum growth and yield.

The variation in the nodulation and effectiveness of the nodules of the varieties as a result of rhizobial inoculation as well as the variation in the $\mathrm{N}$-fixation capability of the strains used agrees with the assertion of FALL \& al. (2003) and who reported that effective symbiotic relationship depends on the cultivar and the rhizobium strain. PULEMEULENBERG \& al. (2010) similarly reported that cowpea genotypes differed significantly in growth, $\mathrm{N}$ content and $\mathrm{N}$ fixation and that the 18 bradyrhizobia strains the authors isolated differed significantly in their $\mathrm{N}_{2}$ fixing efficiency. The effective nodules recovered from the inoculated plants in this study indicates that the strains used were equally effective and they can successfully form symbiosis with cowpea in the study area but they were not as effective as the indigenous strains resident in the soil of the study area considering the better performance recorded in the uninoculated plants.

The better performance exhibited by the uninoculated plants in respect of $\mathrm{N}$-fixed, biomass and grain yield than the inoculated plants is in agreement with the report of ALIYU $\&$ al. (2013) who determined the response of grain legumes to rhizobial inoculation in two savanna soils of Nigeria (Eutric Cambisols and Rhodic Nitisols). The authors reported that cowpea did not respond to rhizobial inoculation and attributed the poor response to the high rhizobial population density in the experimental soils. FENING \& DANSO (2002) reported that there has been low response of cowpea to inoculation probably due to high incidence of 
cowpea bradyrhizobia in most tropical soils and the promiscuous nature of cowpea. Cowpea appears to be the most promiscuous legume which has been intensively studied, nodulating with a wide range of fast and slow growing rhizobia [MPEPEREKI \& al. 2000].

Though the inoculated plants did not perform better than the uninoculated plants in respect of the productivity in this study, the inoculated plants partitioned significantly higher nitrogen to their seeds thereby having higher protein content in the seeds than the uninoculated plants. This concurs with the report of VOLLMANN \& al. (2011) and BEJANDI \& al. (2012) who reported an increase in seed protein content as a result of rhizobial inoculation.

The grain yield obtained in this study $\left(1338-1761 \mathrm{~kg} \mathrm{ha}^{-1}\right)$ though not up to the potential yield of the varieties $\left(2000-2600 \mathrm{~kg} \mathrm{ha}^{-1}\right)$ (Nigerian seed portal, 2018) is a big improvement on the average of $350-450 \mathrm{~kg} \mathrm{ha}^{-1}$ obtained on farmers' fields in Nigeria [KAMAI \& al. 2014; OMOTOSO, 2014]. This could be a pointer to the fact that ineffectiveness of our indigenous rhizobial strains is not the major problem responsible for the low yield obtained on farmers' fields in Nigeria.

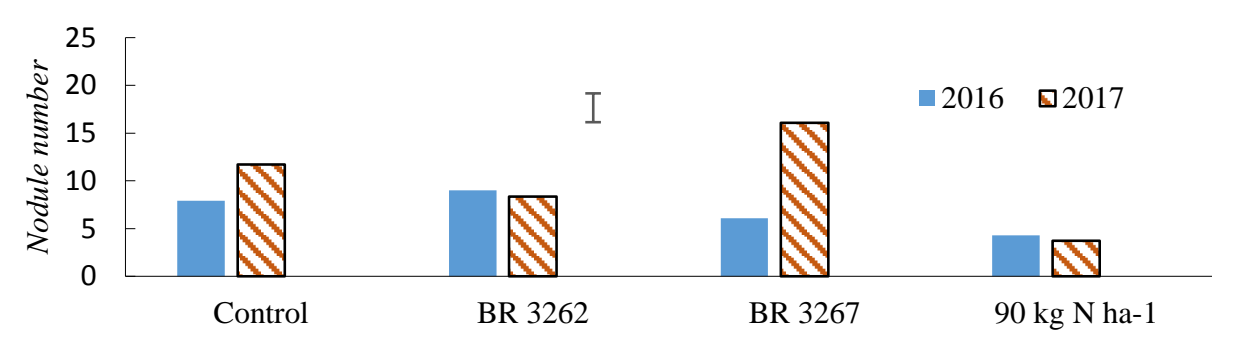

Figure 1. Nodule number of cowpea as affected by rhizobial inoculation across two years, I-LSD $(\mathrm{P}=0.05)$ 
Olaotan Abimbola ADEDIRAN \& al.

Table 1. Mean square values for response of cowpea varieties to rhizobial inoculation

\begin{tabular}{|c|c|c|c|c|c|c|c|c|}
\hline $\begin{array}{l}\text { Source of } \\
\text { variation }\end{array}$ & $\begin{array}{c}\text { Nodule } \\
\text { number } \\
\text { (per plant) }\end{array}$ & $\begin{array}{c}\text { Nodule dry } \\
\text { weight (g/plant) }\end{array}$ & $\begin{array}{c}\text { Nodule } \\
\text { effectiveness } \\
(\%) \\
\end{array}$ & $\begin{array}{c}\text { N-fixed } \\
\left(\mathrm{kg} \mathrm{ha}^{-1}\right)\end{array}$ & $\begin{array}{l}\text { N-uptake } \\
\text { (mg/plant) }\end{array}$ & $\begin{array}{l}\text { Shoot biomass } \\
\text { yield }\left(\mathrm{t} \mathrm{ha}^{-1}\right)\end{array}$ & $\begin{array}{l}\text { Grain yield } \\
\left(\mathrm{t} \mathrm{ha}^{-1}\right)\end{array}$ & $\begin{array}{l}\text { Seed protein } \\
\text { content }(\%)\end{array}$ \\
\hline Year (Y) & $177.00 * *$ & 26.53 & 34.72 & 1174.09 & 118537.14 & 0.06 & 255477.26 & 16.52 \\
\hline Inoculation(I) & $170.02 * *$ & $6190.91 * * *$ & $2656 * * *$ & $7833.27 * *$ & $248255.45^{* *}$ & $2.32 * *$ & $748178.86^{*}$ & $119.96 * *$ \\
\hline Variety (V) & 42.44 & 1464.97 & 816.67 & $8741.88^{* *}$ & $212689.40 * *$ & $3.08 * *$ & 248133.24 & $47.17 * *$ \\
\hline Y x I & $113.37 * *$ & 747.78 & 182.87 & 646.67 & 101792.81 & 0.37 & 385828.72 & 8.97 \\
\hline $\mathrm{YxV}$ & 30.50 & 874.67 & 372.22 & 1346.00 & 65193.67 & 0.49 & 2844856.43 & 13.12 \\
\hline V x I & 5.09 & 57.57 & 577.78 & 1045.24 & 17723.06 & 0.29 & 326999.46 & 12.19 \\
\hline Y x V x I & 45.59 & $2249.11 *$ & $1081.48 * *$ & 748.83 & 42551.37 & 0.60 & 248870.94 & 6.08 \\
\hline
\end{tabular}


Table 2. Nodule dry weight of cowpea as affected by rhizobial inoculation across two years

\begin{tabular}{cccc}
\hline \multirow{2}{*}{ Rhizobial inoculation } & Variety & \multicolumn{2}{c}{ Nodule dry weight (mg/plant) } \\
& IT93K-452-1 & $60.93 \mathrm{abc}$ & $\mathbf{2 0 1 7}$ \\
\hline Control & IT99K-573-1-1 & $31.2 \mathrm{~b}-\mathrm{f}$ & $73.31 \mathrm{a}-\mathrm{e}$ \\
& TVx 3236 & $52.11 \mathrm{a}-\mathrm{d}$ & $21.4 \mathrm{c}-\mathrm{f}$ \\
& IT93K-452-1 & $48.93 \mathrm{a}-\mathrm{e}$ & $37.46 \mathrm{a}-\mathrm{f}$ \\
BR 3262 & IT99K-573-1-1 & $70.98 \mathrm{ab}$ & $20.1 \mathrm{c}-\mathrm{f}$ \\
& TVx 3236 & $35.85 \mathrm{a}-\mathrm{f}$ & $35.85 \mathrm{a}-\mathrm{f}$ \\
& IT93K-452-1 & $33.3 \mathrm{~b}-\mathrm{f}$ & $76.17 \mathrm{ab}$ \\
BR 3267 & IT99K-573-1-1 & $36.74 \mathrm{a}-\mathrm{f}$ & $80.66 \mathrm{a}$ \\
& TVx 3236 & $65.52 \mathrm{abc}$ & $23.31 \mathrm{c}-\mathrm{f}$ \\
& IT93K-452-1 & $13.7 \mathrm{def}$ & $22.8 \mathrm{c}-\mathrm{f}$ \\
& IT99K-573-1-1 & $20.0 \mathrm{c}-\mathrm{f}$ & $1.82 \mathrm{f}$ \\
& TVx 3236 & $4.5 \mathrm{ef}$ & $4.63 \mathrm{ef}$ \\
\hline \multirow{2}{*}{ SE \pm} & & 9.34 & \\
\hline
\end{tabular}

Table 3. Percentage of effective nodules as affected by rhizobial inoculation across two years

\begin{tabular}{cccc}
\hline \multirow{2}{*}{ Rhizobial inoculation } & Variety & \multicolumn{2}{c}{ Effective nodules (\%) } \\
& & $\mathbf{2 0 1 6}$ & $\mathbf{2 0 1 7}$ \\
\hline Control & IT93K-452-1 & $60.00 \mathrm{~b}-\mathrm{f}$ & $66.67 \mathrm{a}-\mathrm{e}$ \\
& IT99K-573-1-1 & $63.3 \mathrm{a}-\mathrm{f}$ & $66.7 \mathrm{a}-\mathrm{e}$ \\
& TVx 3236 & $80 \mathrm{ab}$ & $66.7 \mathrm{a}-\mathrm{e}$ \\
& IT93K-452-1 & $73.33 \mathrm{a}-\mathrm{d}$ & $70.00 \mathrm{a}-\mathrm{d}$ \\
BR 3262 & IT99K-573-1-1 & $40.00 \mathrm{e}-\mathrm{h}$ & $56.67 \mathrm{~b}-\mathrm{g}$ \\
& TVx 3236 & $90.00 \mathrm{a}$ & $70 \mathrm{a}-\mathrm{d}$ \\
BR 3267 & IT93K-452-1 & $56.67 \mathrm{~b}-\mathrm{g}$ & $50.00 \mathrm{c}-\mathrm{g}$ \\
& IT99K-573-1-1 & $90.00 \mathrm{a}$ & $56.67 \mathrm{~b}-\mathrm{g}$ \\
& TVx 3236 & $63.3 \mathrm{a}-\mathrm{f}$ & $70.00 \mathrm{a}-\mathrm{d}$ \\
& IT93K-452-1 & $50.00 \mathrm{c}-\mathrm{g}$ & $36.67 \mathrm{fgh}$ \\
& IT99K-573-1-1 & $46.67 \mathrm{~d}-\mathrm{h}$ & $30.00 \mathrm{gh}$ \\
& TVx 3236 & $20.00 \mathrm{~h}$ & $70 \mathrm{a}-\mathrm{d}$ \\
\hline
\end{tabular}

Means followed by similar alphabets are not significantly different at $\mathrm{P}=0.05$ using LSD 
Olaotan Abimbola ADEDIRAN \& al.

Table 4. N-uptake, shoot biomass yield and seed protein content of cowpea as affected by rhizobial inoculation

\begin{tabular}{lccc}
\hline \multicolumn{1}{c}{ Treatments } & $\begin{array}{c}\text { N-uptake } \\
\text { Rhizobial inoculation }\end{array}$ & $\begin{array}{c}\text { Shoot biomass } \\
\text { yield } \\
\left(\mathbf{m} \mathbf{~ h a}^{-\mathbf{1}} \mathbf{)}\right.\end{array}$ & $\begin{array}{c}\text { Seed protein } \\
\text { content }\end{array}$ \\
\hline Control & 617.45 & 2.35 & 22.05 \\
\hline BR 3262 & 475.77 & 1.95 & 23.80 \\
\hline BR 3267 & 406.74 & 1.64 & 24.00 \\
90 kg N ha & -1 & 2.40 & 24.06 \\
LSD $(0.05)$ & 656.18 & 0.45 & 1.75 \\
\hline
\end{tabular}

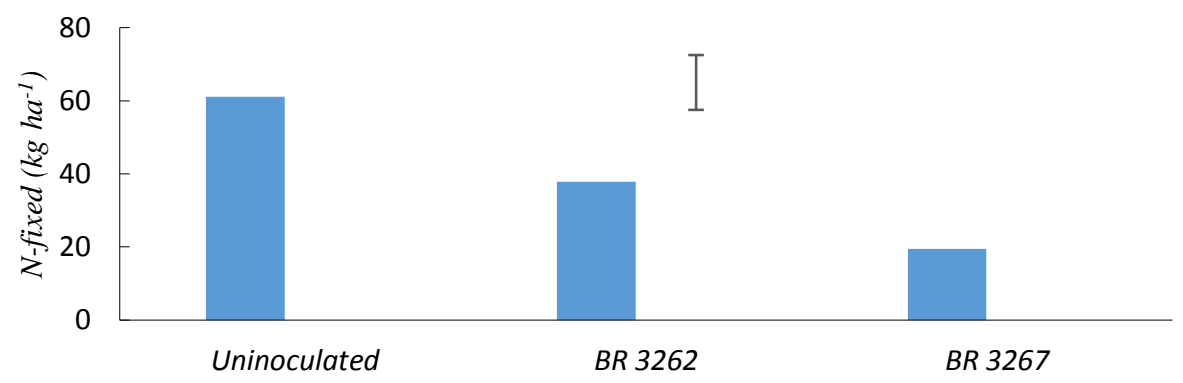

Figure 2a. Effect of rhizobial inoculation on $\mathrm{N}$ fixation of cowpea I- LSD $(\mathrm{P}=0.05)$

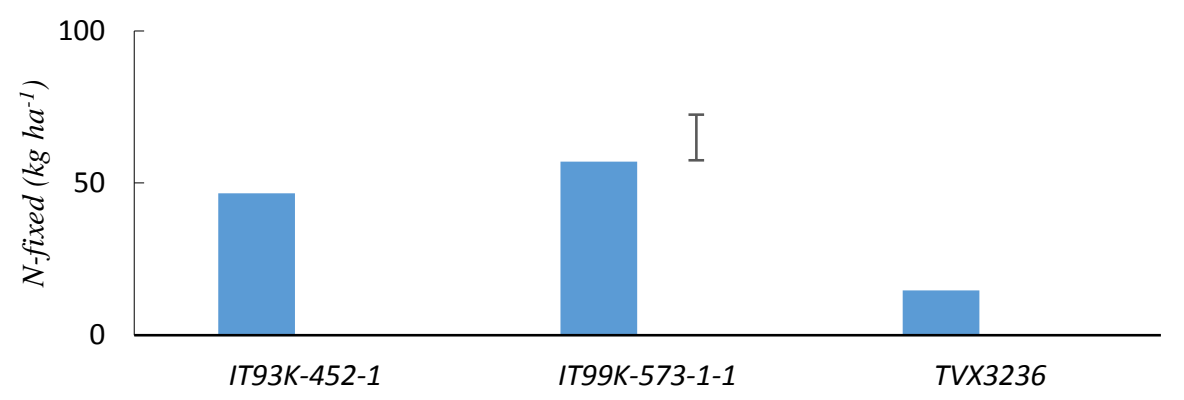

Figure 2b. Varietal effect of cowpea on $\mathrm{N}$-fixation

$$
\text { I-LSD }(\mathrm{P}=0.05)
$$


Table 5. Varietal effect of cowpea on $\mathrm{N}$-uptake, shoot biomass yield and seed protein content of cowpea

\begin{tabular}{lccc}
\hline \multicolumn{1}{c}{ Variety } & $\begin{array}{c}\text { N-uptake } \\
(\mathbf{m g} / \text { plant })\end{array}$ & $\begin{array}{c}\text { Shoot biomass yield } \\
\left(\mathbf{t ~ h a}^{-\mathbf{1}}\right)\end{array}$ & $\begin{array}{c}\text { Seed Protein content } \\
(\mathbf{\%})\end{array}$ \\
\hline IT93K-452-1 & 617.20 & 2.26 & 24.97 \\
IT99K-573-1-1 & 565.37 & 2.32 & 23.27 \\
TVx 3236 & 434.53 & 1.67 & 22.19 \\
LSD $(0.05)$ & 118.53 & 0.39 & 1.51 \\
\hline
\end{tabular}

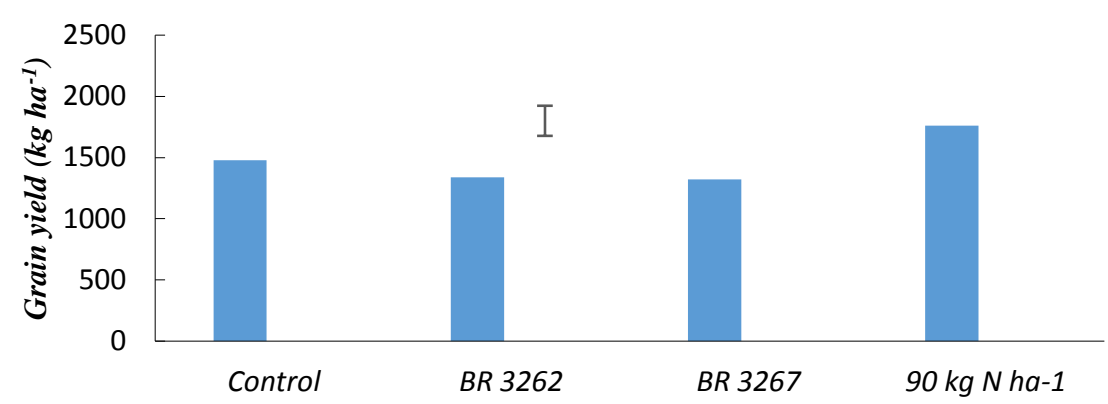

Figure 3. Effect of rhizobial inoculation on grain yield of cowpea

$$
\text { I- LSD }(\mathrm{P}=0.05)
$$

\section{Conclusions}

The BR strains tested in this study were not more effective than the indigenous strains resident in the soil of the study area in improving the $\mathrm{N}$-fixation and productivity of cowpea. More cowpea rhizobia strains should be developed and tested for their effectiveness. Furthermore, other factors such as poor management practices, inappropriate planting date and the cropping system adopted, use of poor quality seeds and unimproved varieties which contribute to low yield of cowpea in the study area should be worked on.

\section{Acknowledgements}

The authors wish to acknowledge Federal University of Technology, Minna and the Institute for Tropical Agriculture (IITA) for the PhD fellowship awarded to O. A. Adediran through the Bill \& Melinda Gates Foundation, in the N2Africa project.

\section{Notes on contributors}

Olaotan Abimbola ADEDIRAN recently completed her PhD studies in Crop Production with specialization in Crop Physiology. Her research interests focus on increasing crop productivity and quality through sustainable management practices. She teaches Crop Physiology and Principles of Crop Production at the Department of Crop Production, Federal University of Technology, Minna.

Akim Osarhiemen OSUNDE is a professor of Soil Science in Federal University of Technology, Minna where he has been contributing to the development of manpower in Agriculture. He has been actively involved in providing the much needed research background for the local use of biological nitrogen fixation by grain, green manure and tree legumes as a low input technology for the management of degraded soils. 
Abdullahi BALA is a Professor of Soil Science with specialization in Soil Microbiology and Sustainable Agriculture. He has varied experience in research for development and Agricultural Policy and has worked with small holder farmers in several African countries.

Mahamadi DIANDA is a soil microbiologist $(\mathrm{PhD})$ focusing on the promotion of biofertilizers in Sahelian agrosystems. His work promotes the establishment of legume inoculants facilities in West Africa and strengthens the adoption of inoculant technologies by smallholder farmers across sub-Saharan Africa. Currently, he is working at the national research institute of Burkina Faso contributing to symbiosis and nutrition of tree crops.

Haruna IBRAHIM holds a PhD in Crop Production. His research interest encompasses effect of mother-plant nutrition on seed quality of crop varieties. He is an Associate Professor and the Deputy Director, Directorate for Collaborations, Affiliations and Linkages of Federal University of Technology (FUT), Minna, Nigeria.

Olusoji Olaolu OLUFAJO is a Professor of Agronomy at the Department of Agronomy, Institute for Agricultural Research, Ahmadu Bello University, Zaria, Nigeria. Professor Olufajo's research focus is integration of legumes into smallholder farming systems, particularly in drought-prone environments. Currently, he is the National Cowpea Coordinator and also the Chairman, Technical SubCommittee (Crops) of the National Crop Varieties and Livestock Breeds Registration and Release Committee.

Johnson Akinade OLADIRAN is a Professor of Crop Production. He started his research career at the National Horticultural Research Institute Ibadan, in 1976 before joining the Federal University of Technology, Minna, Nigeria in 1987. He has contributed to the development of manpower in Agriculture and he has published scholarly papers on the agronomy, seed dormancy and quality of several vegetables and cereal crops.

\section{References}

ALIYU A., YUSUF A. A. \& ABAIDOO R. C. 2013. Response of grain legumes to rhizobia inoculation in two savanna soils of Nigeria. African Journal of Microbiology Research. 7(15): 1332-1342. https://dx.doi.org/10.5897/AJMR12.1127

BEJANDI T. K., SHARIFII R. S., SEDGHI M. \& NAMVAR A. 2011. Effects of plant density, Rhizobium inoculation and microelements on nodulation, chlorophyll content and yield of chickpea (Cicer arietinum L.). Journal of Biological and Agricultural Research. 23: 1067-1178.

BEJANDI T. K., SHARIFII R. S., SEDGHI M. \& NAMVAR A. 2012. Effects of plant density, Rhizobium inoculation and microelements on nodulation, chlorophyll content and yield of chickpea (Cicer arietinum L.). Annals of Biological Research. 3(2): 951-958.

BASHAN Y., DE-BASHAN L. E., PRABHU S. R. \& HERNANDEZ J. 2014. Advances in plant growth promoting bacterial inoculant technology: formulations and practical perspectives (1998-2013). Plant and soil. 378(1): 1-33. https://doi.org/10.1007/s11104-013-1956-x

ELKOCA E., KANTAR F. \& SAHIN F. 2007. Influence of nitrogen fixing and phosphorus solubilizing bacteria on the nodulation, plant growth, and yield of chickpea. Journal of plant nutrition. 31: 157-171. https://doi.org/10.1080/01904160701742097

FALL L., DIAGA D., MAME A. F., FRANÇOIS A. B. \& MAMADOU G. 2003. Genetic diversity in cowpea (Vigna unguiculata (L.) Walp.) varieties determined by ARA and RAPD techniques. African Journal of Biotechnology. 2(2): 48-50. http://dx.doi.org/10.5897/AJB2003.000-1009

FENING J. O. \& DANSO S. K. A. 2002. Variation in the symbiotic effectiveness of cowpea Bradyrhizobia indigenous to Ghananian soils. Applied Soil Ecology. 21: 23-29. DOI: 10.1016/S0929-1393(02)00042-2

FENING J. O., DOGBE W. O. \& DANSO S. K. A. 2001. Assessment of the potential to improve N fixation by cowpea (Vigna unguiculata (L.) Walp.) in Ghanaian soils. American Journal of Alternative Agriculture. 16(2): 57-65. DOI:10.1017/s0889189300008924

HAN H. S. \& LEE K. D. 2005. Physiological responses of soybean to inoculation with Bradyrhizobium japonicum in saline soil conditions. Research Journal of Agriculture and Biological Sciences. 1(3): 216-221.

HUANG H. C. \& ERICKSON R. S. 2007. Effect of Seed Treatment with Rhizobium leguminosarum on pythium damping-off, seedling height, root nodulation, root biomass, shoot biomass, and seed yield of pea and lentil. Journal of Phytopathology. 155: 31-37. https://doi.org/10.1111/j.1439-0434.2006.01189.x 


\section{SYMBIOTIC EFFECTIVENESS OF BRAZILIAN RHIZOBIAL STRAINS IN IMPROVING ...}

IITA \& N2AFRICA. 2014. Legume inoculation technology. A manual prepared by International Institute for Tropical Agriculture (IITA) and nitrogen to Africa (N2Africa). Available from: http://biblio.iita.org/documents/U14ManIitaLegumeNothomNodev.pdf-fb3408313162eaa6a34bbff5 e9664684.pdf [assessed 2/7/15].

KAMAI N., GWORGWOR N. A. \& WABEKWA J. W. 2014. Varietal trials and physiological components determining yield differences among cowpea varieties in semiarid zone of Nigeria. ISRN Agronomy, 2014, Article ID 925450. http://dx.doi.org/10.1155/2014/925450

KENNEDY I. R., CHOUDHURY A. \& KECSKÉS M. L. 2004. Non-symbiotic bacterial diazotrophs in crop-farming systems: can their potential for plant growth promotion be better exploited? Soil Biology and Biochemistry. 36: 1229-1244. https://doi.org/10.1016/j.soilbio.2004.04.006

LARANJO M., ALEXANDRE A. \& OLIVEIRA S. 2014. Legume growth-promoting rhizobia: an overview of Messorhizobium genus. Microbiological Research. 169: 2-17. https://doi.org/10.1016/j.micres.2013.09.012

MATIRU V. N. \& DAKORA F. D. 2004. Potential use of rhizobia bacteria as promoters of plant growth for increased yield in landraces of African cereal crops. African Journal of Biotechnology. 3: 1-7. http://dx.doi.org/10.5897/AJB2004.000-2002

MFILINGE A., KELVIN M. \& NDAKIDEMI P. 2014. Effects of Rhizobium inoculation and supplementation with $\mathrm{P}$ and $\mathrm{K}$, on growth, leaf chlorophyll content and nitrogen fixation of bush bean varieties. American Journal of Research Communication. 2(10): 49-87.

MPEPEREKI S., JAVAHERI F., DAVIS P. \& GILLER K. E. 2000. Soyabeans and sustainable agriculture. Promiscuous soyabeans in southern Africa. Field Crops Research. 65(2-3): 137-149. https://doi.org/10.1016/S0378-4290(99)00083-0

OJANUGAA. G. 2006. Agroecological Zones of Nigeria Manual. FAO/NSPFS, Federal ministry of Agriculture and Rural Development, Abuja, Nigeria, 124 pp.

OMOTOSO S. O. 2014. Influence of NPK 15-15-15 fertilizer and pig manure on nutrient dynamics and production of cowpea, Vigna unguiculata L. Walp. American Journal of Agriculture and Forestry. 2(6): 267-273. https://doi.org/10.11648/j.ajaf.20140206.16

PULE-MEULENBERG F., BELANE A. K., KRASOVA-WADE T. \& DAKORA F. D. 2010. Symbiotic functioning and bradyrhizobial biodiversity of cowpea (Vigna unguiculata L. Walp.) in Africa. BMC Microbiology. 10: $89-101$. https://doi.org/10.1186/1471-2180-10-89

SINGH B. B., CHAMBLISS O. L. \& SHARMA B. 1997. Recent advances in cowpea breeding. pp. 30-49. In: SINGH B. B., MOHAN RAJ D. R., DASHIELL K. E. \& JACKAI L. E. N. (eds.). 1997. Advances in cowpea research. International Institute of Tropical Agriculture (IITA) and Japan International Research Center for Agricultural Sciences (JIRCASS), IITA, Ibadan, Nigeria, 375 pp.

SCHWEIGER P., HOFER M., HARTL W., WANEK W. \& VOLLMANN J. 2012. N 2 fixation by organically grown soybean in Central Europe: Method of quantification and agronomic effects. European Journal of Agronomy. 41: 11-17. https://doi.org/10.1016/j.eja.2012.01.011

TAJIMA R., LEE O. N., ABE J., LUX A. \& MORITA S. 2007. Nitrogen-fixing activity of root nodules in relation to their size in peanut (Arachis hypogaea L.), Plant Production Science. 10(4): 423-429, https://doi.org/10.1626/pps.10.423

VOLLMANN J., WALTER H., SATO T. \& SCHWEIGER P. 2011. Digital image analysis and chlorophyll metering for phenotyping the effects of nodulation in soybean. Computers and Electronics in Agriculture. 75(1): 190-195. https://doi.org/10.1016/j.compag.2010.11.003

YAKUBU H., KWARI J. D. \& NGALA A. L. 2010. N $\mathrm{N}_{2}$ fixation by grain legume varieties as affected by rhizobia inoculation in the sandy loam soil of Sudano-sahelian zone of North Eastern Nigeria. Nigerian Journal of Basic and Applied Science. 18(2): 229-236. http://dx.doi.org/10.4314/njbas.v18i2.64325

ZHOU X. J., LIANG Y., CHEN H., SHEN S. H. \& JING Y. X. 2006. Effects of rhizobia inoculation and nitrogen fertilization on photosynthetic physiology of soybean. Photosynthetica. 44(4): 530-535. https://doi.org/10.1007/s11099-006-0066-x

How to cite this article:

ADEDIRAN O. A., OSUNDE A. O., BALA A., DIANDA M., IBRAHIM H., OLUFAJO O. O. \& OLADIRAN J. A. 2019. Symbiotic effectiveness of brazilian rhizobial strains in improving N-fixation and productivity of cowpea in Minna, southern Guinea savanna of Nigeria. J. Plant Develop. 26: 23-34. https://doi.org/10.33628/jpd.2019.26.1.23 